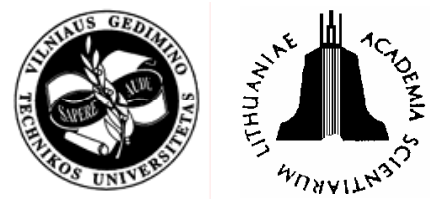

\title{
ELASTIC-PLASTIC FRACTURE ANALYSIS OF STRUCTURAL COLUMNS
}

\author{
Abdesselam Zergua and Mohamed Naimi \\ Dept of Civil Engineering, University of Constantine, Route Ain El Bey - Constantine, Algeria \\ E-mail :zergua_abdeslem@yahoo.fr,m_naimi03@yahoo.fr \\ Received 19 June 2005; accepted 29 Sept 2005
}

\begin{abstract}
This research is achieved in the general frame-work of the study of the concrete behaviour. It has for objective the development of a numerical tool able to predict the behaviour of reinforced concrete columns with circular and square cross-sections under an increasing compressive axial load. The concrete behaviour is assumed as elastic-plastic model with an associated flow rule in compression region and as elastic with tension stiffening behaviour in the tension region. Two yield surfaces have been taken into account according to the Drucker-Prager and Rankine failure criterions. However, the reinforcing steel is assumed as an elastic strain hardening model. A finite element method using solid cube elements for concrete, and bar elements for the reinforcement have been used. Correlation study between numerical and experimental results is conducted with the objective to establish the validity of the proposed model and identify the significance of the transverse reinforcement volumetric ratio effect on the response of reinforced concrete members. Good agreement has been observed in comparing these results.
\end{abstract}

Keywords: reinforced concrete column, elastic-plastic modelling, numerical simulation, finite elements, transverse reinforcement.

\section{Introduction}

Reinforced concrete members are commonly designed to satisfy two criteria in terms of the serviceability and safety. In order to ensure the serviceability requirement, it is necessary to predict accurately the response of $\mathrm{r} / \mathrm{c}$ structure to working loads. There are various approaches to modelling the global behaviour of $\mathrm{r} / \mathrm{c}$ members in finite element applications (Oller et al [1], Lembit et al [2], Hauke et al [3], Kwon and Spacon [4]). The developed models range from very sophisticated laws based on plasticity theory that rely on the definition of a plastic flow rule and on the separation of the deformation increments into plastic and elastic components, to simpler models based on phenomenological rules. However, under tensile stresses and due to its brittleness, concrete cracks and eventually looses strength entirely. If this brittleness could be reduced or even overcome, many advantages would be gained. In recent years, both experimental and theoretical studies have done for evaluating the effect of passive confinement provided by lateral reinforcement for improving the mechanical properties of concrete columns under different loads. As a result, material models that take into account the effect of confinement have been proposed by Mander et al [5], Ahmad and Shah [6], Shamin and Toklucu [7], Sheikh and Uzumeri [8], Pallewatta et al [9]. It has been shown that a high ductility and strength of reinforced concrete can be achieved if the volume of stirrups and the reinforcement configurations are provided sufficiently $[5,7,9,10]$ and the post-peak behaviour depends in general on the level of lateral confinement. Under low confinement, the post-peak response is a brittle softening. For increasing confinement stresses, the response of concrete changes to ductile hardening [11].

This study deals with the analysis of the monotonic behaviour of structural reinforced concrete. A finite elements program is developed to have a better understanding of the reinforced concrete columns response under an increasing compressive loading, while maintaining a certain computational simplicity to allow analyses of structural elements with reasonable computational efforts. This tool is developed in order to have a rapid stress-strain evaluation without using more sophisticated and expensive tools. It is based on the elastic-plasticfracture modelling. The compressive concrete is considered as elastic-plastic with the Drucker-Prager failure criterion [12]. However, the smeared crack hypothesis has been taken into account for tensile cracking with Rankine yield surface. Concrete and reinforcing steel are represented by separate material models which are combined together to describe the behaviour of the composite reinforced concrete material. The reinforcing steel is considered as elastic strain hardening model. Three dimensional solid elements and one dimensional element are adopted to represent the concrete and the steel reinforcement, respectively. The stiffness matrix of the composite 
element is obtained by summation of material stiffness of the individual material components. Perfect bonding between concrete and reinforcement is assumed. A parametric study is carried out by analysing the effect of lateral reinforcement on the stress-strain curves.

\section{Material behaviour model}

\subsection{Concrete behaviour model}

Concrete is a non-homogeneous, anisotropic material whose response is non-linear even under low-stress levels ( $30 \%$ of its maximum compressive strength [13]). Furthermore, it exhibits a different behaviour under tension and compression stresses: a non-linear stress-strain relationship, strain softening and anisotropic stiffness reduction, cracks due to tensile stresses and strains, slip between concrete and steel and time-dependent behaviour such as creep and shrinkage.

From a macroscopic point of view, the concrete behaviour is explained in the following stages: hardening behaviour, softening behaviour, plastic failure, and tensile cracking.

Among various models proposed for predicting the behaviour of concrete, this paper uses an elasticplastic-fracture model where the element, initially, behaves in an isotropic linear elastic manner until reaching a yield value. Cracking or crushing of the element is initiated once the stress, at an element integration point, exceeds the yield surface defined by the appropriate failure criterions. Cracked or crushed regions, as opposed to discrete cracks, are then formed perpendicular to the relevant principal stress direction with stresses being redistributed locally.

The governing relationships for different stages are given as:

\subsubsection{Linear elastic region}

The stress-strain increment relation is given as:

$$
\{d \sigma\}=[D]\{d \varepsilon\}
$$

where

$\{d \sigma\}$ and $\{d \varepsilon\}$ are the stress and strain increment vectors;

$[D]$ - elastic material stiffness matrix [13].

\subsubsection{Plastic hardening and softening region}

The concrete yielding occurs, when the stress state reaches the yield surface defined by DruckerPrager failure criterion. After yielding, the incremental constitutive relationship will be expressed [14] as:

$$
\{d \sigma\}=[D]^{e p}\{d \varepsilon\}
$$

with

$$
\{d \varepsilon\}=\left\{d \varepsilon^{e}\right\}+\left\{d \varepsilon^{p}\right\}
$$

$\left\{d \varepsilon^{e}\right\}$ - elastic strain increment vector;

$\left\{d \varepsilon^{p}\right\}$ - plastic strain increment vector. It is given according to the concept of normality as follows:

$$
\left\{d \varepsilon^{p}\right\}=d \lambda\left\{\frac{\partial f(\sigma)}{\partial \sigma}\right\}
$$

$d \lambda$ : Plastic multiplier. It is given as in [14].

$$
d \lambda=\frac{\left\{\frac{\partial f(\sigma)}{\partial \sigma}\right\}^{T}[D]}{A+\left\{\frac{\partial f(\sigma)}{\partial \sigma}\right\}^{T}[D]\left\{\frac{\partial f(\sigma)}{\partial \sigma}\right\}}\{d \varepsilon\},
$$

$[D]^{e p}$ - elasto-plastic stiffness matrix, for associated plasticity it is expressed as

$$
[D]^{e p}=[D]-\frac{[D]\left\{\frac{\partial f(\sigma)}{\partial \sigma}\right\}\left\{\frac{\partial f(\sigma)}{\partial \sigma}\right\}^{T}[D]}{A+\left\{\frac{\partial f(\sigma)}{\partial \sigma}\right\}^{T}[D]\left\{\frac{\partial f(\sigma)}{\partial \sigma}\right\}},
$$

where

$f(\sigma)$ - yield function defined by Drucker-Prager failure criterion [12].

$A$ - hardening parameter. It is considered to be the slope of the uniaxial stress - plastic strain curve [14]. It is equal to zero if the behaviour is assumed as elastic-perfect plastic.

$$
A=\frac{E_{c} E_{T}}{E_{c}-E_{T}},
$$

$E_{c}$ and $E_{T}$ - elastic and plastic modulus of concrete.

\subsubsection{Tensile cracked concrete}

Prior to cracking, concrete is modelled sufficiently accurately as a linear elastic material. Once cracking has occurred, according to Rankine failure criterion, the tensile cracking is modelled via a smeared cracking model in which the tensile stress of crack surfaces is released gradually (Fig 1), and the element stiffness matrix changes from isotropic to lateral isotropic, which is identical to the complete crack development [15, 16]. The residual stiffness during cracking is expressed [17] as:

$$
[D]=\left[\begin{array}{ccccc}
\frac{1-v^{2}}{\Delta} & \frac{v(1+v)}{\Delta} & \frac{v(1+v)}{\Delta} & & \\
& \frac{1}{\Delta}\left(\frac{1}{\mu}-v^{2}\right) & \frac{1}{\Delta}\left(\frac{v}{\mu}+v^{2}\right) & 0 & \\
& \frac{1}{\Delta}\left(\frac{1}{\mu}-v^{2}\right) & & \\
& & \frac{E}{2(1+v)} & \\
& & & \frac{\mu E}{2(1+v)} & \\
& & & & \frac{\mu E}{2(1+v)}
\end{array}\right]
$$

where 
where

$$
\begin{gathered}
\Delta=\frac{\left[\frac{\left(1-v^{2}\right)}{\mu}-2 v^{2}(1+v)\right]}{E_{c}}, \\
\mu=\frac{-E\left(\varepsilon_{f}-\varepsilon_{t}\right)}{E_{c} \varepsilon_{t}},
\end{gathered}
$$

with $\mu$ - cracking factor; $E$ - tangent softening modulus and has a negative value; $v$ - Poisson's ratio; $\varepsilon_{f}-$ strain at the end of crack formation; $\varepsilon_{t}-$ current tensile strain; $\sigma_{t}$ - direct tensile strength.

As $\mu=1$ corresponds to the beginning of the cracking. When $\varepsilon_{t} \rightarrow \varepsilon_{f}, \quad \sigma_{t} \rightarrow 0$ and $\mu \rightarrow 0$ indicating that the state of complete cracking is reached.

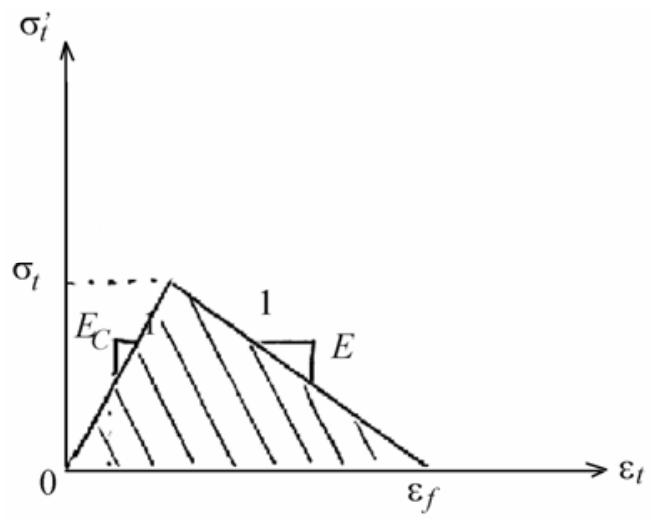

Fig 1. Assumed stress-strain curve for concrete in tension

\subsection{Steel behaviour model}

Longitudinal and transverse steel reinforcement are assumed as truss members carrying axial forces only. They are modelled as an additional stiffness in a specified orientation connected to the solid elements. They are assumed as elastic - strain hardening plastic model. One dimensional bar element with one degree of freedom per node is used for modelling them.

\section{Finite element formulation}

Based on the above relations, the finite element formulation is used to solve the governing differential equations for the required stress and strain distribution. Three dimensional cubic elements for concrete (20-node elements with three degrees of freedom per node) [18], and linear elements (3 node Lagrange elements with one degree of freedom per node) are adopted to represent, respectively, concrete and steel reinforcement. Due to the symmetry of the column geometry and reinforcement, only one fourth of the section is taken into account (Fig 2). The stiffness matrix of the composite element is obtained by summation of the individual material components, concrete and reinforcement.

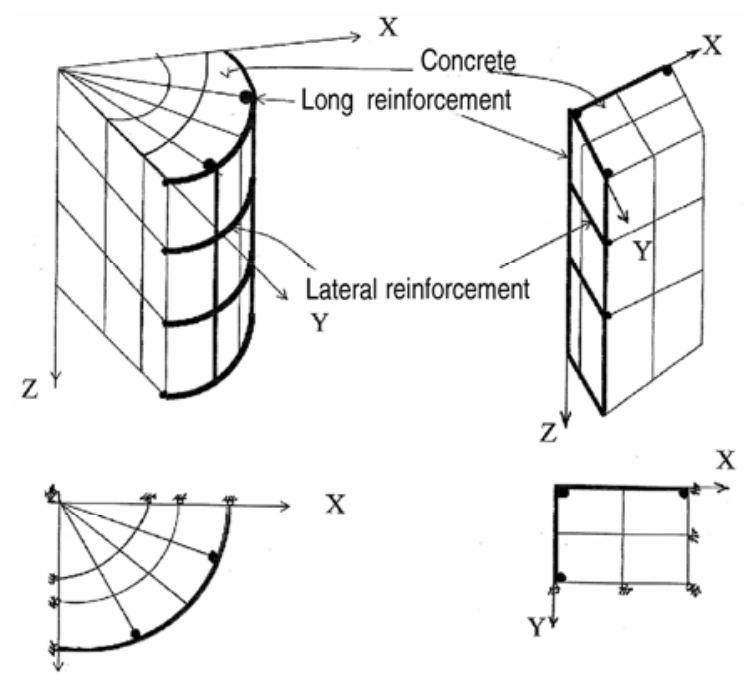

$\mathrm{Y}$

Circular section

Square section

Fig 2. Discretisation of columns

The formulation includes a smeared crack analogy for cracking in tension zones and a plasticity theory to account for the possibility of concrete crushing in compression zones. Each element has 8 integration points at which cracking and crushing checks are performed. The material behaviour of concrete is described by two failure surfaces in stress space. Concrete is assumed as a linear elastic material for stress states which lie inside the initial yield surface. Crushing or cracking of concrete takes place when the stresses lie outside the ultimate surface in the stress space.

\section{Non-linear procedure}

A material behaves elastically as long as a limiting stress state described by the yield surface is not exceeded. The displacements increments $\{\Delta d\}$ are obtained from the equation $\left[K_{T}\right]\{\Delta d\}=\{R\}$, where $\left[K_{T}\right]$ is the tangent stiffness matrix evaluated at the previous iteration and $\{R\}$ is the residual load vector. As long as this relation is linear and the stiffness corresponds to $\left[K_{T}\right]$, the equilibrium will be gained by default. The method adopted to solve this system of equations is the Gaussian elimination and back substitution process [19]. Beyond the elastic limit, the problem will be thus non-linear and requires an iterative solver. The Newton Raphson non-linear method is adopted in which the tangent stiffness matrix is updated at the beginning of each iteration [14]. The iterative cycles are repeated until the convergence is reached.

The algorithm used in the analysis is summarised for one load increment as follows:

1 - Solve equilibrium equation $\left[K_{T}\right]\{\Delta d\}=\{R\}$;

2 - Add displacement increment $\{\Delta d\}$ to the current displacement $\{d\}$; 
3 - For all elements and all integration points update the strains and stresses:

$\left\{\sigma^{e}\right\}=\{\sigma\}+[D]\left\{d \varepsilon^{e}\right\}$, (exponent 'e" for elastic state);

4 - evaluate the yield function $f$ using failure criterion:

if $f<0$ gauss point is elastic. Goto step 5

if $f \geq 0$ Gauss point is yielded. Compute the stresses using elasto-plastic return mapping algorithm [13];

5 - Compute the internal load vector $\left\{F_{\text {ext }}\right\}$;

6 - Check convergence.

If convergence does not occur, update $\{R\}$ and $\left[K_{T}\right]$ Goto step 1

7 - stop.

\section{Discussion of results}

In order to validate the developed program, numerical results for both circular and square section ordinarily reinforced short columns are compared to experimental models issued from the literature revue. The material characteristics considered are as follows: the compressive strength, tensile strength and Young's modulus of concrete are, respectively, $25 \mathrm{MPa}, 4 \mathrm{MPa}$ and $3.10^{4} \mathrm{MPa}$. The yield strength, elastic and plastic modulus of reinforcement are, respectively, $240 \mathrm{MPa}, 2.10^{5} \mathrm{MPa}$ and $2.10^{4} \mathrm{MPa}$. The cross-sectional area is the same of both the circular and square section.

Figs 3 and 4 present a comparison between stress-strain curves obtained by the present study and those predicted by Mander et al [5] and Mendis et al [10]. Legend of simbols used in Fig 3 and 4 is given in Table 1. In both cases of circular and square sections, a good agreement is observed between these different results. It is also confirmed that a greater volumetric ratio of transverse reinforcement ( $\rho$ ) did provide an increase in strength and gives the columns a more ductile behaviour in the post-peak region.

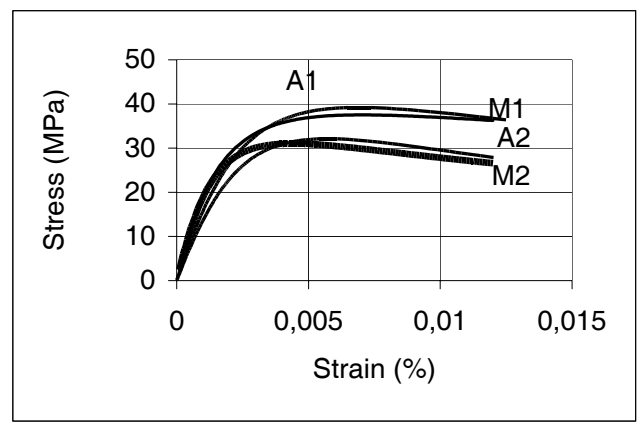

Fig 3. Comparison between analysis and predicted results of Mander et al (circular section)

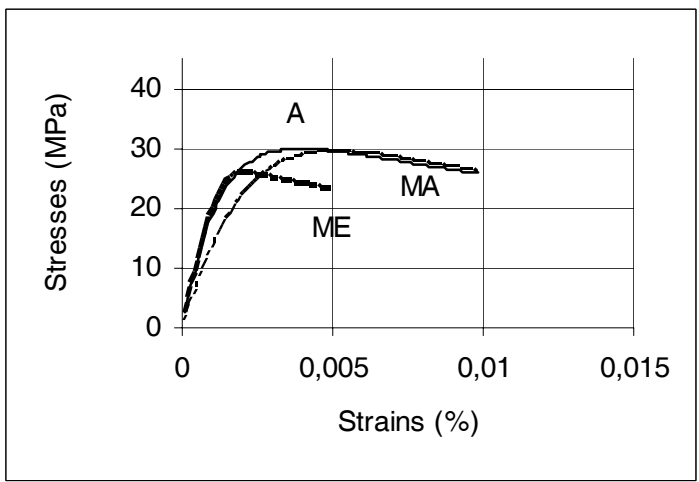

Fig 4. Comparison between analysis and predicted results of Mander et al and Mendis et al (square section, $\rho s=1,9 \%$ )

The variation of the maximum strength of confined concrete for different volumetric ratios of lateral reinforcements are shown in the Figs 5 and 6. The numerical results, in comparison with those predicted by Mander et al in both cases of circular and square sections, show an acceptable value.

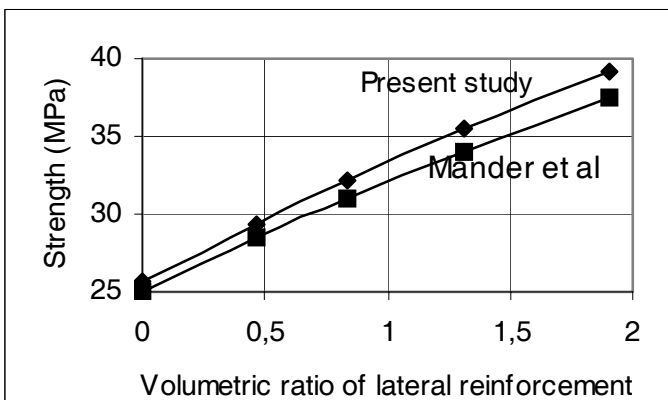

(\%)

Fig 5. Effect of volumetric ratio on strength of circular section

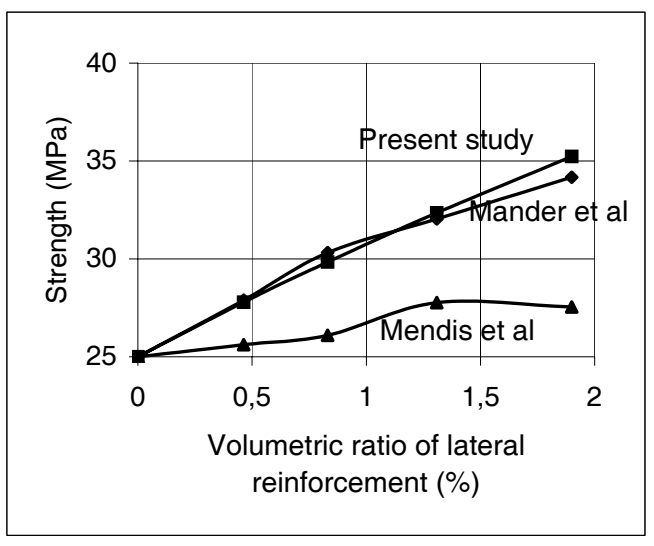

Fig 6. Effect of volumetric ratio on strength of square section

Table 1. Legend of symbols used in Figs 3 and 4

\begin{tabular}{l|c|c|c|c|c|c|c}
\hline \multicolumn{1}{c|}{ Letters } & A1 & A2 & M1 & M2 & A & MA & ME \\
\hline Significance & Analysis & Analysis & Mander & Mander & Analysis & Mander & Mendis \\
\hline $\begin{array}{l}\text { Volumetric ratio of lateral } \\
\text { reinforcement (\%) }\end{array}$ & 1,9 & 0,8 & 1,9 & 0,8 & 1,9 & 1,9 & 1,9 \\
\hline
\end{tabular}


It is also seen from the Figs 7 and 8 that the ultimate strain of columns increased in proportion to the increased transverse reinforcement volumetric ratio. The circular section columns exhibit greater values of strains that those observed in the square section.

The descending or softening portion of the stress-strain relationship is important when investigating the ductility of columns. Fig 9 shows the variation of the slope of this curve branch as obtained in the present work. The angle between the vertical axis and the tangent line of this branch increases with the volumetric ratio of transverse reinforcement ( $\rho s)$. It is more significant in case of a circular section. The increasing angle (or decreasing slop) confirms that a greater volumetric ratio provides an increase in the columns ductility in the post-peak region.

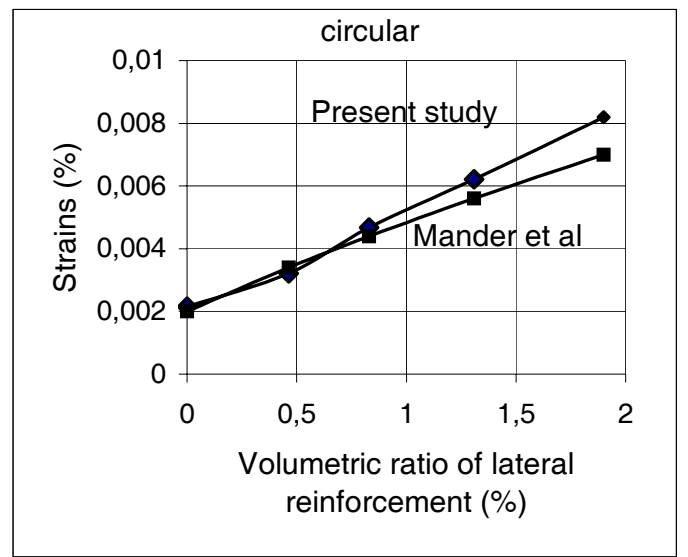

Fig 7. Variation of the ultimate strain for different volumetric ratio (circular section)

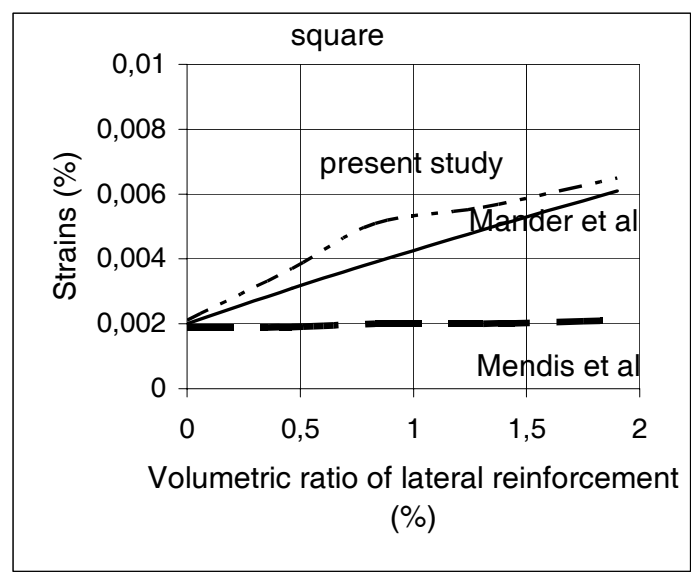

Fig 8. Evolution of the ultimate strain for different volumetric ratio (square section)

Fig 10 shows a comparison between the stressstrain curves obtained by the developed program in the case of circular and square section for $0,8 \%$ of transverse reinforcement volumetric ratio.

It can be seen in Figs 3-8 that the lateral reinforcement is more effective in the case of the circular columns. This is because the reinforcement provides a continuous confining pressure around the circumference of the circular section and results in the increased concrete strength and ultimate strain. However, the confining pressure is more dominant at the corner of the square section, since the sides of the members tend to bend outward due to lower restraint against lateral displacement, which reduces the confinement efficiency. This obviousness is reported by several researchers: Irawan and Maekawa [20], Sargin [21], Ahmad and Shah [6], Sheikh and Uzumeri [8].

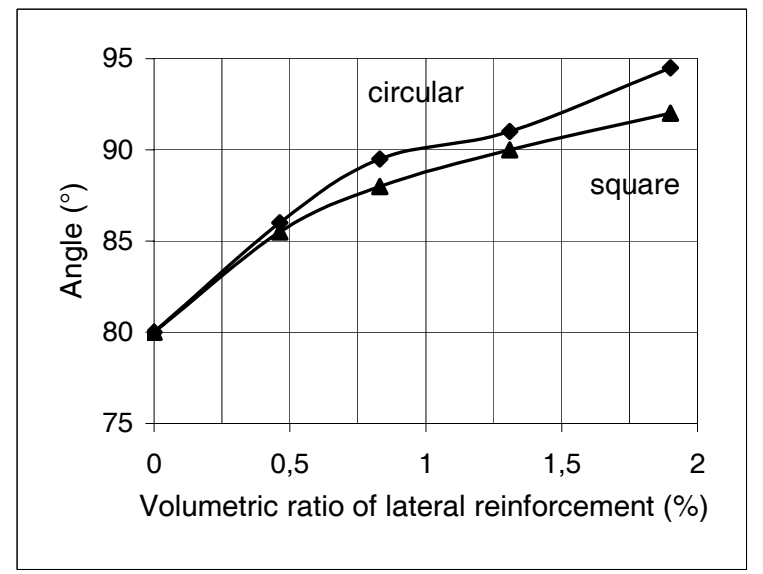

Fig 9. Effect of volumetric ratio on the slope of descending portion of stress-strain curves

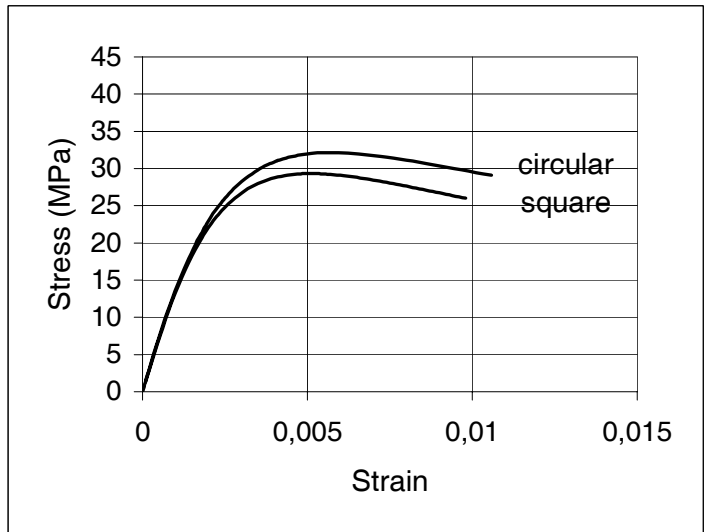

Fig 10. Analysis stress-strain curves for circular and square sections $\left(\rho_{\mathrm{s}}=0,8 \%\right)$

\section{Conclusions}

The numerical program developed in this study, using the finite element method is proposed to the purpose of accurately predicting the behaviour of reinforcing concrete columns, and is also capable of simulating their behaviour under the increasing axial compressive load. It is developed in order to have a rapid stress-strain evaluation.

Finite element method with elasto-plasticfracture modelling is used to describe the material behaviour. The smeared crack analogy for cracking in tension zones and a plasticity theory for crushing in compression zones are included. 
Numerical results are presented and compared to those of Mander et al and Mendis et al. A good correlation between the computed and the experimental results has been observed when comparing different curves. It has been also confirmed that the ductile behaviour of confined columns and gain strength can be achieved by increasing the volumetric ratio of lateral reinforcement.

\section{References}

1. Oller, S.; Onate, E.; Oliver, J. and Lubliner, J. Finite element nonlinear analysis of concrete structures using a plastic damage model. Engineering Fracture Mechanics, Vol 35, No 1-3, 1990, p. 219-231.

2. Lembit, M. K. and Maciuj, P. B. Elasto-plastic constitutive equations of stiffened plates. Journal of Engineering Mechanics, ASCE, Vol 114, No 4, 1988, p. 656-669.

3. Hauke, B. and Maekawa, K. Three-dimensional modelling of reinforced concrete with multi-directional cracking. Journal of Materials, Concrete Structures and Pavements, JSCE, Vol 45, No 634, 1999, p. 349-368.

4. Kwon, M. and Spacone E. Three-dimensional finite element analyses of reinforced concrete columns. Computers and Structures, Vol 80, Issue 2, 2002, p. 199-212.

5. Mander, B. J.; Priestley, M. J. N. and Park, R. Theoretical stress-strain model for confined concrete. Journal of Structural Engineering, ASCE, Vol 114, No 8, 1988, p. 1804-1826.

6. Ahmad, S. M. and Shah S. P. Stress-strain curves of concrete confined by spiral reinforcement. ACI Journal, Vol 79, No 6, 1982, p. 484-490.

7. Sheikh, S. A. and Toklucu, M. T. Reinforced concrete columns confined by circular spirals hoops. ACI Structural Journal, Sept / Oct 1993, Vol 90, Issue 5, p. 542-553.

8. Sheikh, S. A. and Uzumeri, S. M. Strength and ductility of tied concrete colmns. Journal of the Structural Division, ASCE, Vol 106, No 5, 1980, p. 1079-1102.
9. Pallewatta, T. M.; Irawan, P. and Maekawa, K. Confinement effectiveness of lateral reinforcement arrangements in core concrete. Journal of Materials, Concrete Structures and Pavements, JSCE, Vol 28, No 520, 1995, p. 221-247.

10. Mendis, P. A.; Kovacic, D. and Setung, D. Basis for the design of lateral reinforcement for high-strength concrete columns. Structural Engineering and Mechanics, Vol 9, No 6, 2000, p. 589-600.

11. Smith, S.; Willam, K.; Gerstle, K. and Sture, S. Concrete over the top, or: is there life after peak? ACI Journal, Vol 86, No 5, 1989, p. 491-497.

12. Drucker, D. C. and Prager, W. Soil mechanics and plastic analysis or limit design. Quarterly of Applied Mathematics, Vol 10, No 2, 1952, p. 157-165.

13. Chen, W. F. Plasticity in reinforced concrete. McGraw Hill Book Company, 1982. 465 p.

14. Hinton, E. and Owen, D. R. J. Finite elements in plasticity, theory and practice. Pineridge Press Limited, Sweansea, UK, 1980. 594 p.

15. Bazant, Z. P. and Oh, B. H. Crack bond theory for fracture of concrete. Materials and Structures, Vol 16, No 93, 1983, p. 155-177.

16. Rachid, Y. R. Ultimate strength analysis of pretressed concrete pressure vessels. Nuclear Engineering and Design, Vol 7, Issue 4, 1968, p. 334-344.

17. Han, D. J. and Chen, M. Constitutive modelling in analysis of concrete structures. Journal of Engineering Mechanics, ASCE, Vol 113, No 4, 1987, p. 577-591.

18. Zienkiewicz, O. C. The finite element method. 3rd ed, McGraw Hill, 1977. 787 p.

19. Smith, I. M. and Griffiths, D. V. Programming the finite element method. John Wiley \& Sons, 1988. 469 p.

20. Irawan, P. and Maekawa, K. Strength and damage analysis of concrete confined by steel casing. Journal of Materials, Concrete Structures and Pavements, JSCE, Vol 20, No 472, 1993, p. 97-106.

21. Sargin, M. Stress-strain relationships for concrete and the analysis of structural concrete sections. Study No 4, Solid Mechanics Division, University of Waterloo. 1971, p. 167.

\section{TAMPRIAI PLASTINIŲ KOLONŲ ANALIZE், TAIKANT PAŽAIDŲ MECHANIKOS PRINCIPUS}

\section{A. Zergua and M. Naimi}

\section{Santrauka}

Tyrimuose nagrinèta betono elgsena. Pagrindinis darbo tikslas - sukurti skaitini algoritmą augančia ašine gniuždymo jẻga veikiamų apskrito bei kvadratinio skerspjūvio gelžbetoninių kolonų elgsenai analizuoti. Betono elgsenai modeliuoti taikytas tampriai plastinès medžiagos modelis. Gniuždomojo betono modelyje ívertintos plastinės deformacijos. Tempiamosios zonos betono modelyje įvertinta armatūros ir betono sąveika ruožuose tarp plyšių. Betonui modeliuoti taikytas Drucker-Prager plastiškumo modelis ir Rankine irimo kriterijus. Armatūrai imtas stiprejjančios medžiagos idealizuotasis modelis. Skaičiavimai atlikti taikant baigtinių elementų metodą. Diskretizuojant betoną, taikyti kubiniai erdviniai baigtiniai elementai, o modeliuojant armatūra, - strypiniai baigtiniai elementai. Pasiūlytojo modelio tikslumui bei skersinès armatūros kiekio ịtakos kolonų laikomajai galiai ịvertinti atlikta skaitinių skaičiavimų ir eksperimentinių tyrimų rezultatų koreliacinè analizè. Gautas geras teorinių ir eksperimentinių rezultatų sutapimas.

Reikšminiai žodžiai: gelžbetoninẻ kolona, tampriai plastinis modeliavimas, skaitinis modeliavimas, baigtiniai elementai, skersinè armatūra.

Abdesselam ZERGUA. Research Assistant in the Civil Engineering Department at the University of Constantine, Algeria. His research deals with the mechanical behaviour of reinforced concrete and the design of concrete structures.

Mohamed NAIMI. Senior Lecturer in Civil Engineering Department at the University of Constantine, Algeria. His research interests cover earthquake resistance of reinforced concrete, the seismic behaviour of r/c- soil system and reinforced concrete mechanics of concrete structures. 